\title{
The Tertiary relict tree Zelkova abelicea (Ulmaceae): distribution, population structure and conservation status on Crete
}

\author{
Gregor Kozlowsi, David Frey, Laurence Fazan, Bernhard Egli \\ Sébastien Bétrisey, Joachim Gratzfeld, Giuseppe Garfì \\ and STERGIOS PIRINTSOS
}

\begin{abstract}
Relict species provide a unique opportunity to understand past and recent biogeographical and evolutionary processes. Zelkova abelicea (Ulmaceae), which is endemic to the island of Crete (Greece), is one of the most prominent Tertiary relict trees of the Mediterranean region. We collected distribution, threat and population structure data by reviewing literature and herbaria and through field surveys at 14 study plots throughout the range of the species. The present distribution of $Z$. abelicea is extremely fragmented. Although the total estimated number of individuals is relatively high, the populations are dominated by dwarf, severely browsed, non-flowering individuals. The population structure is asymmetric. At most, $5 \%$ of a plot's trees are large and fruit-bearing. The asymmetric structure is particularly pronounced in isolated and small populations. Based on its limited geographical range, the fragmented spatial pattern, and data on distribution and population structure, our study confirms that $Z$. abelicea is a threatened species (IUCN category Endangered). Our research aim is to promote the development of new approaches for the improvement of conservation strategies for Tertiary relict trees characterized by major local disjunctions.
\end{abstract}

Keywords Area of occupancy, conservation status, conservation strategy, Crete, extent of occurrence, relict tree, threatened species, Zelkova abelicea

This paper contains supplementary material that can be found online at http://journals.cambridge.org

GREgor KozlowsKi ${ }^{*}$ (Corresponding author), DAVID FreY and SÉBASTIEN BÉTRISEY Department of Biology and Botanic Garden, University of Fribourg, Chemin du Musée 10, CH-1700 Fribourg, Switzerland. E-mail gregor. kozlowski@unifr.ch

LAUREnCE FaZAN Department of Geosciences, Conservation Biogeography, University of Fribourg, Switzerland, and Institute for Environmental Sciences, University of Geneva, Switzerland

Bernhard Egli Bioforum, Schaffhausen, Switzerland

JoACHIM GraTZFeld Botanic Gardens Conservation International, Richmond, Surrey, UK

GiUsepPe Garfi National Research Council, Institute of Plant Genetics, Palermo, Italy

Stergios Pirintsos Department of Biology, University of Crete, Greece, and Botanical Garden, University of Crete, Greece

${ }^{*}$ Also at: Natural History Museum, Fribourg, Switzerland

Received 6 March 2012. Revision requested 20 June 2012.

Accepted 23 August 2012. First published online 5 August 2013.

\section{Introduction}

$T$ he Mediterranean and adjacent regions are considered 1 among the most important refugial zones of the Tertiary relict flora in western Eurasia (Milne \& Abbott, 2002; Milne, 2006), including relict trees of the genera Aesculus, Juglans, Liquidambar, Pterocarya and Zelkova (Browicz, 1982). Most of these relicts have a restricted distribution and are at risk of extinction, often with only a few natural populations that survived the last glaciation in isolated areas or on Mediterranean islands (Quézel \& Médail, 2003; Connor, 2009; Garfi et al., 2011).

Zelkova abelicea (Lam.) Boiss. (Ulmaceae), a Tertiary relict tree endemic to the Greek island of Crete, is one of two European representatives of this otherwise Asiatic genus (Fineschi et al., 2002, 2004; Kozlowski \& Gratzfeld, 2013). The second Mediterranean species, Z. sicula, was discovered in 1991 in Sicily (Di Pasquale et al., 1992). The genus has a particularly disjunct distribution. In addition to the two Mediterranean species, one species occurs in Transcaucasia (Z. carpinifolia) and three in eastern Asia (Z. serrata, $Z$. schneideriana and Z. sinica; Zheng-yi \& Raven, 2003; Denk \& Grimm, 2005). The isolation of the east Asiatic and west Eurasian taxa most likely began in the Middle Miocene as a result of increasing aridity in central Asia. In western Eurasia Zelkova became restricted to refugia during the Pleistocene ice ages (Wang et al., 2001). The establishment of a summer dry climate in the Mediterranean area during the Quaternary further contributed to the fragmentation of the range of the genus. Zelkova had already disappeared from continental Greece by the Middle Pleistocene, C. 400,000 BP, but persisted in central Italy until c. 30,000 BP (Follieri et al., 1986; Van der Wiel \& Wijmstra, 1987).

Relict species such as $Z$. abelicea provide a unique opportunity to understand past and recent biogeographical and evolutionary processes. The species is one of the most notable Tertiary relict trees of the Mediterranean region because it is found at higher altitudes than other relict trees such as Liquidambar orientalis and Phoenix theophrasti. Moreover, it is one of the few tree species endemic to the eastern Mediterranean. For these reasons the species is of scientific and conservation interest (Kozlowski \& Gratzfeld, 2013).

All four of the main Cretan mountain ranges hold populations of $Z$. abelicea: the Levka Ori, Psiloritis, Dhikti 

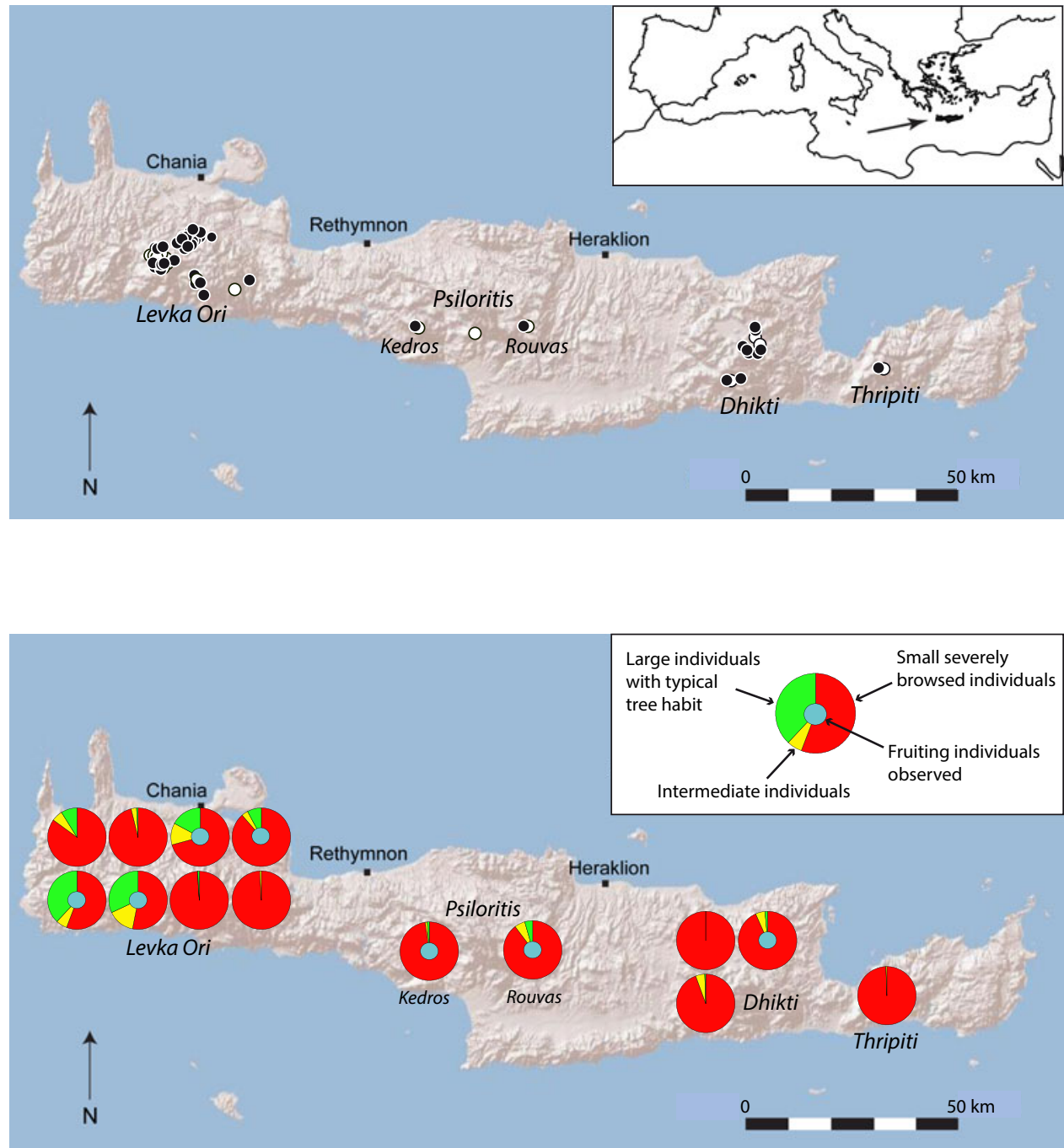

FIg. 1 Historical and recent distribution of Zelkova abelicea. Black circles: recently observed and/or described populations (1993-2010). White circles: presumably extinct populations known from literature and herbaria (1700-1992).
FIG. 2 Population structure of Z. abelicea in the 14 study plots (Table 1). and Thripiti Mountains (Jahn \& Schönfelder, 1995; Rackham \& Moody, 1996; Fazan et al., 2012; Kozlowski \& Gratzfeld, 2013). Z. abelicea is found in open mountain forests, where it coexists with Acer sempervirens, Quercus coccifera and occasionally Cupressus sempervirens (Egli, 1997). The species primarily occupies north-facing slopes and areas around dolines, although it can also grow in or near rocky river beds and gullies, where moisture tends to remain near the surface during the dry summer (Søndergaard \& Egli, 2006; Fazan et al., 2012).

Despite its emblematic status among conservationists and dendrologists (de Spoelberch, 1993), Z. abelicea has never been studied or monitored comprehensively throughout its range (Kozlowski et al., 2012a).

Our aims were to (1) update current knowledge on the historical and recent distribution of $Z$. abelicea, (2) gather data to improve our understanding of the population structure of Z. abelicea and the threats that it faces, based on study plots in selected populations across its range, and (3) re-evaluate the conservation status of the species to contribute to the design of conservation measures based on new evidence. This study is the first to examine the populations of the species in all four mountain ranges of Crete.

\section{Study area}

The island of Crete in the southern Aegean Sea (Fig. 1) is one of the largest islands of the Mediterranean basin $\left(8,729 \mathrm{~km}^{2}\right)$, with a landscape dominated by karst mountains. Crete has a typical Mediterranean climate, with hot, dry summers and cool, wet winters. At higher elevations annual precipitation can exceed $2,000 \mathrm{~mm}$ and snowfall is not unusual during winter, although snow accumulates only above 1,400 m, where it may persist until May (Rackham \& Moody, 1996). Precipitation is higher in the western part of the island, and moisture from winter precipitation may be stored locally in the soil throughout the summer (Egli, 1997). Crete is a remnant of an island arc that once connected Greece to Turkey and it has been separated from the mainland for at least 5 million years (Schüle, 1993). This 
TABLE 1 The 14 plots where Zelkova abelicea was surveyed (Supplementary Fig. S1), with altitude, area and the intensity of occurrence of threats to the species: overgrazing by livestock, drought and other forms of water stress, wood exploitation (e.g. pollarding, cutting of branches), soil erosion and/or rockfall, geographical isolation, and signs of recent fires. For conservation reasons, the exact coordinates of the study plots are not provided.

\begin{tabular}{|c|c|c|c|c|c|c|c|c|}
\hline Site (ID) & $\begin{array}{l}\text { Altitude } \\
(\mathrm{m})\end{array}$ & $\begin{array}{l}\text { Plot area } \\
\left(\mathrm{m}^{2}\right)\end{array}$ & Overgrazing* & Drought $^{*}$ & $\begin{array}{l}\text { Wood } \\
\text { exploitation }^{\star}\end{array}$ & Erosion $^{*}$ & Isolation* & Fire \\
\hline \multicolumn{9}{|l|}{ Levka Ori Mountains } \\
\hline Omalos (OMA1) & 1223 & 4,789 & +++ & - & + & +++ & - & No \\
\hline Omalos (OMA2) & 1231 & 14,321 & +++ & - & + & +++ & - & No \\
\hline Omalos (OMA3) & 1041 & 500 & ++ & - & - & - & - & No \\
\hline Omalos (OMA4) & 1050 & 1,500 & ++ & - & - & - & - & No \\
\hline Ambelitsias Potamos (AMB1) & 1269 & 2,500 & ++ & - & + & + & - & No \\
\hline Ambelitsias Potamos (AMB2) & 1429 & 1,852 & +++ & - & + & + & - & Yes \\
\hline Eligas Gorge (ELI) & 1591 & 3,616 & ++ & ++ & - & + & ++ & Yes \\
\hline Niato (NIA) & 1226 & 1,465 & ++ & - & - & - & ++ & Yes \\
\hline \multicolumn{9}{|l|}{ Psiloriti Mountains } \\
\hline Mt. Kedros (KED) & 1280 & 20,522 & ++ & - & - & + & +++ & Yes \\
\hline Rouvas Forest (PSI) & 1335 & 5,993 & ++ & ++ & - & ++ & +++ & Yes \\
\hline \multicolumn{9}{|l|}{ Dhikti Mountains } \\
\hline Kéfala (LAS1) & 1195 & 3,083 & ++ & - & - & - & + & No \\
\hline Mt. Dhikti (LAS2) & 1374 & 775 & ++ & - & - & ++ & + & No \\
\hline Mt. Dhikti (LAS3) & 1373 & 823 & ++ & ++ & - & +++ & + & No \\
\hline \multicolumn{9}{|l|}{ Thripiti Mountains } \\
\hline Afendis Kavousi (STA) & 1145 & 964 & ++ & - & - & - & +++ & Yes \\
\hline
\end{tabular}

${ }^{*}-$, negligible or not observed; +, relatively low; ++, strong; +++, extreme

isolation is consistent with its significant value as a floristic refugium because $>10 \%$ of its 1,700 plant species are endemic to the island (Turland et al., 1993).

\section{Methods}

We established the historical and recent distribution of $Z$. abelicea using several sources. As well as carrying out detailed field surveys we reviewed literature and visited herbaria and collections with the most comprehensive holdings of specimens from Crete, including Geneva, Lyon, Montpellier, Paris, Fribourg, Berlin and Kew (Holmgren \& Holmgren, 1998). We defined as historical all natural occurrences of $Z$. abelicea recorded between the first known herbarium records (AD 1700) and the first detailed publication of Egli (1993), which contains the most comprehensive modern data source for the abundance and distribution of $Z$. abelicea. Thus, the recent occurrences include all populations observed and described between 1993 and 2010.

We carried out an additional in situ survey of selected populations of $Z$. abelicea in summer 2010. We visited 14 plots in all four mountain regions with known Zelkova populations (Table 1, Supplementary Fig. S1). Eight plots were selected in the Levka Ori Mountains and three in the Dhikti Mountains. The survey in the Thripiti Mountains was restricted to the only known population of $Z$. abelicea.
In the Psiloritis Mountains the survey was restricted to the two known populations, one in the Rouvas Forest and one on Mount Kedros. In small populations (areas of $<1$,000 $\mathrm{m}^{2}$ ) the plot included the entire stand, and for larger populations with less clearly defined limits, plots of various sizes (500 to $>20,000 \mathrm{~m}^{2}$ ) were used (Supplementary Table S1). In larger populations two or more plots were surveyed to ensure that any environmental heterogeneity was covered by the sampling.

In each study plot we determined the geographical coordinates and altitude, assessed observed and potential threats using a standardized form, counted the number of $Z$. abelicea individuals and noted the presence or absence of fruiting trees. Trees were recorded as being in one of three categories: (1) trees that had a fully developed crown, that had escaped browsing except for the lowest branches and that produced fruit, (2) wholly browsed trees of shrubby dwarfed habit that did not produce fruit, and (3) an intermediate category with browsed lower branches and unbrowsed upper branches that were not yet producing fruit. This classification does not incorporate age but rather attempts to represent the vitality of a given tree (Fazan et al., 2012).

The geographical extent, with coordinates, of all known stands of $Z$. abelicea was mapped, and the calculation of population sizes by Egli (1993 \& unpubl. data) and in this work was completed during field surveys in summer 2010 . The extent of occurrence is defined as the area contained 
within the shortest continuous imaginary boundary that can be drawn to encompass all the known, inferred or projected sites of present occurrence of a taxon, excluding cases of vagrancy, and the area of occupancy is defined as the area within the extent of occurrence that is occupied by a taxon, excluding cases of vagrancy. Both of these areas, the latter based on a cell size of $2 \times 2 \mathrm{~km}$, were calculated according to IUCN (2010) using the online tool developed by the Royal Botanic Gardens, Kew (GeoCAT, 2012).

\section{Results}

\section{Historical and recent distribution of $Z$. abelicea}

Fig. 1 illustrates the distribution of $Z$. abelicea during $1700-$ 2010 on the basis of historical literature, herbarium records and recent observations. The occurrence of $Z$. abelicea in the Levka Ori was known to the scientific community at the beginning of the 18th century (Supplementary Table S2), in the Dhikti Mountains in the second half of the 19th century, and on Mount Kedros and in the Rouvas Forest in the first half of the 2oth century. The small, isolated population in the Thripiti Mountains was discovered during the second half of the 2oth century.

The recent distribution of Z. abelicea (1993-2010) concurs almost completely with the historical occurrences, with no dramatic shifts in distribution during the previous 300 years. However, several isolated populations, primarily in the Levka Ori and Psiloritis Mountains, appear to have become extinct during the second half of the 2oth century (Fig. 1, Supplementary Table $S_{3}$ ). We did not discover any new populations during field surveys.

There are 42 known populations of $Z$. abelicea (Fig. 1, Supplementary Table $S_{3}$ ), 30 in the Levka Ori Mountains and nine in the Dhikti Mountains. There are two populations in the Psiloritis Mountains, one on the northern slopes of Mount Kedros and the other in the Rouvas Forest. Only one small population is known in the Thripiti Mountains.

The species is found up to altitudes of almost $1,800 \mathrm{~m}$ in the Levka Ori Mountains, up to c. 1,600 m in the Dhikti Mountains, and the populations in the Psiloritis and Thripiti Mountains are at 1,150-1,350 m (Table 1, Supplementary Table S3).

The extent of occurrence of the species is $2,094 \mathrm{~km}^{2}$ and the area of occupancy $64 \mathrm{~km}^{2}$. Most of the area of occupancy is located in the Levka Ori Mountains (80\%), with $19 \%$ in the Dhikti Mountains and $0.3 \%$ in each of the other three populations (Supplementary Table $\mathrm{S}_{4}$ ).

\section{Population structure and species abundance}

In all 14 surveyed plots most individuals were dwarf and severely browsed (Fig. 2, Supplementary Table S1). In the
Psiloritis, Dhikti and Thripiti Mountains $90-100 \%$ of the trees were dwarf. Only in the Levka Ori Mountains did we find populations with fewer heavily browsed trees (e.g. OMA2: $53 \%$; OMA1: 56\%). Between 0 and $15 \%$ of individuals were in the intermediate category, and in most study plots $0-17 \%$ of trees were normally developed, with only two plots in the Levka Ori Mountains having higher levels (OMA1: 38\%; OMA2: 32\%). Several study plots had abnormally developed trees (e.g. STA, NIA). In $\mathrm{LAS}_{3}$ only severely browsed individuals were present. We observed that only fully developed trees produced fruit. Fruiting was observed in only half of the study plots (Fig. 2).

A total of 6,007 individuals of $Z$. abelicea were counted in the 14 study plots (Supplementary Table S1). Of these, 91\% $(5,459)$ were severely browsed and dwarf and only $5 \%(320)$ had a normally developed habit. Four percent (228 individuals) were intermediate trees, with branches recently freed from browsing.

The density of trees was relatively high $\left(1,328 \mathrm{ha}^{-1}\right.$; Supplementary Table $\mathrm{S} 1$ ). However, because most trees were severely browsed and dwarf, the mean density of intermediate and large trees was low (39.9 and $27.5 \mathrm{ha}^{-1}$, respectively). Generally, density was higher in severely browsed populations (Supplementary Table $\mathrm{S}_{1}$ ). These populations were characterized by dwarf individuals, most likely of clonal origin. Populations with higher percentages of large trees were less dense (OMA2: $265 \mathrm{ha}^{-1}$; OMA1: $\left.448 \mathrm{ha}^{-1}\right)$.

The total area of all mapped Z. abelicea populations was 884.7 ha (Supplementary Table $S_{4}$ ). Given the mean density of $Z$. abelicea (Supplementary Table S1), it is possible to estimate the total number of individuals of $Z$. abelicea. There could be a total of $>1,000,000$ dwarf $Z$. abelicea individuals in the four mountain ranges studied. Although large trees constitute only a small proportion of the $Z$. abelicea populations, there could be as many as 20,000 normally developed and fruiting individuals (the majority in the Levka Ori Mountains).

\section{Threats}

Table 1 and Fig. 2 show that the most severe pressure on all investigated populations is overgrazing and browsing by livestock. This is followed by soil erosion, which is clearly correlated with intensive trampling and grazing and was observed in almost $60 \%$ of the plots. The potential influence of drought during the summer months is difficult to establish, although symptoms of water stress (e.g. dead branches without signs of browsing, dry and brownish leaves during the vegetative period) were observed in several study plots (e.g. ELI, PSI and LAS3). Pollarding and other forms of wood utilization appear to be minimal and were observed only in plots with a 
relatively large number of normally developed trees (e.g. in the Levka Ori Mountains). Fires are a significant source of disturbance to the vegetation of Crete, and signs of recent burning were observed in $>40 \%$ of the study plots. Finally, the population in the Thripiti Mountains, the two distant populations in the Psiloritis Mountains and several populations in the Dhikti and Levka Ori (e.g. ELI, NIA) are geographically isolated (most likely without gene flow between other populations).

\section{Discussion}

Range fragmentation and the importance of disjunct populations

Our data suggest that the fragmentation of the distribution of $Z$. abelicea (Fig. 1) occurred prior to the modern botanical exploration of Crete c. 300 years ago. Although Crete has a long history of human presence and disturbance (Cowling et al., 1996; Atherden \& Hall, 1999) it is not clear whether this fragmented distribution is a result of anthropogenic impacts, including habitat transformation. Whether or not Crete was dominated by continuous woodland before the arrival of man is subject to debate (Schüle, 1993; Fielding \& Turland, 2005). Grazing and browsing are known to have occurred on the island long before human inhabitants arrived, as Crete was inhabited during the Pleistocene by large herbivores, including species of deer Candiacervus cretensis, dwarf elephant Palaeoloxodon chaniensis and hippopotamus Hippopotamus creutzburgi (Rackham \& Moody, 1996), which required large, prairie-like feeding grounds. It is therefore possible that the range of $Z$. abelicea always consisted of patches, even if these shifted to higher or lower altitudes and expanded or contracted over time. $Z$. abelicea is a temperate Holarctic element of the Cretan flora (Thompson, 2005), occurring exclusively at sites with relatively high water abundance: at higher elevations, on northern slopes and in or around dolines (Søndergaard \& Egli, 2006). As a result of dramatic climatic changes associated with Pleistocene glacial cycles, $Z$. abelicea either migrated to or survived only in these most suitable sites after the end of the Ice Age.

Whatever the causes of this fragmentation (a complex colonization history, climate change, browsing by large Pleistocene herbivores or more recent agricultural practices), gene flow between remote populations is improbable because of the limited dispersal capacity of seeds (Hoshino, 1990), as is the case for all Zelkova species. Thus, the species does not appear to have a metapopulation structure. The interaction of spatially discrete populations appears to be extremely limited. Recolonization through a colonization-extinction dynamic in small geographically isolated populations is not expected to compensate for extinctions (Hanski, 1998). In addition, the relictual nature of $Z$. abelicea suggests that the extant populations have been isolated from each other for a long time.

\section{Altitudinal range}

Z. abelicea occurs at high elevations in supra- and oroMediterranean mixed discontinuous woody stands dominated by evergreen and deciduous trees (Sarlis, 1987; Søndergaard \& Egli, 2006). Palaeobotanical data indicate that the genus Zelkova belongs to a hygro-meso-thermophilous floristic unit that occurred abundantly throughout Europe before the last glacial age (Di Pasquale et al., 1992; Quézel \& Médail, 2003). The Hyrcanian-Euxinian forests of the Transcaucasian region are the last remnants of this flora in western Eurasia (Browicz, 1989). Z. carpinifolia thrives there at $100-600 \mathrm{~m}$, although it can grow at higher altitudes (e.g. at 1,200 $\mathrm{m}$ in Talysh, Azerbaijan), where it occurs only in a shrubby form (Kvavadze \& Connor, 2005). In China the three eastern Asian Zelkova species occur in forests that are functionally similar to each other, and they usually grow to $30-35 \mathrm{~m}$ in height and occur mostly at 200$2,500 \mathrm{~m}$. The Mediterranean species $Z$. sicula, endemic to Sicily, is known only from two relict populations at c. 350 and $500 \mathrm{~m}$. The species grows in thermophilous evergreen and semideciduous oak wood communities in a typical thermo/meso-Mediterranean bioclimate. However, this may not be the optimum environment for the species (Garfi et al., 2011). It is therefore assumed that both Mediterranean Zelkova species survived the Ice Age at lower altitudes and/or latitudes. After the Holocene climate warming, migration of $Z$. abelicea towards more suitable habitats could have been facilitated by effective, although reduced, sexual propagation. $Z$. sicula, however, reproduces exclusively through vegetative multiplication (Garfi et al., 2002).

\section{Dwarf trees and asymmetric population structure}

Of the $>6,000$ Z. abelicea surveyed only 320 (c. 5\%) had a well-developed main stem and crown and usually produced flowers and fruits. Our findings show that, with a few exceptions in the Levka Ori Mountains, the populations of $Z$. abelicea are dominated by dwarf individuals. This asymmetry in the population structure is especially pronounced in relatively small and isolated populations (e.g. in Thripiti, where there are no normally developed trees) and should be considered in any conservation planning. Most previous conservation efforts have focused on well-developed trees, which are visible elements of the landscape (Fazan et al., 2012).

There are many potential causes for the dwarf habit. For $Z$. abelicea the most important are intensive browsing and 
water stress (Fazan et al., 2012), along with the further constraining factors of fire, low nutrient availability, and coppicing and pollarding (Rackham \& Moody, 1996). Generally, the intensity of browsing and grazing in populations of $Z$. abelicea is unusual in comparison with other Zelkova species. Both known populations of Z. sicula and the majority of those of $Z$. carpinifolia are browsed exclusively by cows. On Crete, the principal and omnipresent domestic herbivores are goats and sheep, whose grazing and browsing are more intense and have a major impact on tree habit and vigour.

\section{Conclusions and recommended priority actions}

Z. abelicea is an atypical member of its genus for the following reasons: (1) it can grow at the timberline, (2) it is significantly affected by ovine and caprine (rather than bovine) grazing pressure, (3) it shows a pronounced dimorphism of individuals (dwarf and normally developed trees), and (4) it has an asymmetric population structure dominated by dwarf trees (Kozlowski \& Gratzfeld, 2013). Moreover, Z. abelicea is the only member of the genus with wax ornamentation on the leaf surface, which is thought to be an adaptation to the dry summer of the Mediterranean climate (Wang et al., 2001; Denk \& Grimm, 2005). It is likely that the species escaped historical extinction because of the complex topography of Crete and the suitable climatic conditions (e.g. high precipitation) in the island's mountain regions.

Given the fragmented spatial pattern of the limited geographical range of $Z$. abelicea (with an extent of occurrence $<5,000 \mathrm{~km}^{2}$ and an area of occupancy $<500 \mathrm{~km}^{2}$ ) and the characteristics of the species, we conclude that $Z$. abelicea is a threatened species (IUCN category Endangered, EN). The formal evaluation according to the IUCN Red List Categories and Criteria is Blab(iii) + $2 \mathrm{ab}$ (iii). The results described in this study were used in the most recent IUCN status assessment of the species (Kozlowski et al., 2012b).

An action plan and a series of workshops dedicated to the conservation of $Z$. abelicea are in preparation. We recommend the following priority actions in collaboration with the local authorities:

\section{In situ conservation of the species' entire range}

The fragmentation of $Z$. abelicea populations requires that each mountain massif where the species occurs should represent a separate conservation unit, with locally adapted conservation strategies. Core populations of immediate conservation concern, identified on the basis of geographic isolation, area covered and browsing pressure, include the sole population in the Thripiti Mountains and the Mount
Kedros and Rouvas Forest populations in the Psiloritis range. Each of these isolated, and in some cases small, populations is at risk of being lost as a result of an accidental, deliberate or stochastic event (e.g. fire, road construction, drought). Effective methods and measures to limit and/or completely prevent livestock grazing need to be developed in close collaboration with shepherds and other local stakeholders and accompanied by long-term scientific surveys to monitor progress and allow adaptive management.

\section{Enhance ex situ conservation}

A major coordinated effort is required to establish viable, representative and well-documented collections at botanic gardens, arboreta and other affiliated institutions in collaboration with forest services in Greece, and especially Crete. The $Z$. abelicea collections cultivated in botanic gardens almost exclusively originate from the Levka Ori region (the most accessible area and the best-known occurrence of the species), therefore new collections based on plants from all other regions would significantly enhance the ex situ conservation value. Additionally, as the species is not present in any international seed bank, new seed collections should be undertaken. In particular, this should include collections from the small, highly isolated and threatened populations of Psiloritis, Dhikti and Thripiti, from where plant material has rarely, if ever, been collected for ex situ cultivation.

\section{Foster public awareness of national botanical riches}

Greece is endowed with a diverse flora, including unique, endemic and relict species such as $Z$. abelicea, and there is enormous potential to raise public awareness of this national biological wealth. Botanic gardens, especially in or near major urban centres, are ideal venues for developing a range of environmental campaigns and outreach activities, supported by educational materials and interactive exhibitions.

\section{Acknowledgements}

We thank Benoît Clément and Susanne Bollinger, Botanical Garden of the University of Fribourg (Switzerland), Emanuel Gerber and André Fasel, Natural History Museum Fribourg (Switzerland), Vaios Kalogrias (University of Crete) and Yann Marbach for their assistance during fieldwork and manuscript preparation. We are indebted to Fondation Franklinia for its generous support for this study, and to Douglas Gibbs (Botanic Gardens Conservation International) and Melanie Bilz (IUCN). Permission to investigate $Z$. abelicea populations was granted by the 
Ministry of the Environment, General Directorate of Forests, Department of Aesthetic Forests, National Parks and Wildlife Management, Athens, Greece (199076/1843).

\section{References}

Atherden, M.A. \& Hall, J.A. (1999) Human impact on vegetation in the White Mountains of Crete since AD 500. Holocene, 9, 183-193.

BRowicz, K. (1982) Chorology of Trees and Shrubs in South-West Asia and Adjacent Regions. Polish Academy of Sciences, Institute of Dendrology, Bogucki Wydawnictwo Naukowe, Poznan, Poland.

BRowicz, K. (1989) Chorology of the Euxinian and Hyrcanian element in the woody flora of Asia. Plant Systematics and Evolution, 162, 305-314.

Connor, S.E. (2009) Human impact-the last nail in the coffin for ancient plants? Journal of Biogeography, 36, 485-486.

Cowling, R.M., Rundel, P.W., Lamont, B.B., Kalin Arroyo, M. \& Arianoutsou, M. (1996) Plant diversity in Mediterranean-climate regions. Trends in Ecology and Evolution, 11, 362-366.

Denk, T. \& Grimm, G.W. (2005) Phylogeny and biogeography of Zelkova (Ulmaceae sensu stricto) as inferred from leaf morphology, ITS sequence data and the fossil record. Botanical Journal of the Linnean Society, 147, 129-157.

De Spoelberch, P. (1993) Zelkova: more questions than answers! International Dendrological Society Yearbook, 1993, 30-33.

Di Pasquale, G., Garfì, G. \& Quézel, P. (1992) Sur la présence d’un Zelkova nouveau en Sicile sud-orientale (Ulmaceae). Biocosme Mésogéen, 8-9, 401-409.

Egli, B. (1993) Ökologie der Dolinen im Gebirge Kretas (Griechenland). $\mathrm{PhD}$ thesis, ETH Zürich, Switzerland.

EGLI, B. (1997) A project for the preservation of Zelkova abelicea (Ulmaceae), a threatened endemic tree species from the mountains of Crete. Bocconea, 5, 505-510.

Fazan, L., Stoffel, M., Frey, D.J., Pirintsos, S. \& Kozlowski, G. (2012) Small does not mean young: age estimation of severely browsed trees in anthropogenic Mediterranean landscapes. Biological Conservation, 153, 97-100.

Fielding, J. \& Turland, N. (2005) Flowers of Crete. Royal Botanic Gardens, Kew, UK.

Fineschi, S., Anzidei, M., Cafasso, D., Cozzolino, S., Garfì, G., PAstorelli, R. et al. (2002) Molecular markers reveal a strong genetic differentiation between two European relic tree species: Zelkova abelicea (Lam.) Boissier and Z. sicula Di Pasquale, Garfi \& Quézel (Ulmaceae). Conservation Genetics, 3, 145-153.

Fineschi, S., Cozzolino, S., Migliaccio, M. \& Vendramin, G.G. (2004) Genetic variation of relic tree species: the case of Mediterranean Zelkova abelicea (Lam.) Boissier and Z. sicula Di Pasquale, Garfi and Quézel (Ulmaceae). Forest Ecology and Management, 197, 273-278.

Follieri, M., Magri, D. \& SAdori, I. (1986) Late Pleistocene Zelkova extinction in central Italy. New Phytologist, 103, 269-273.

Gandoger, M. (1916) Flora cretaica. A. Herman et Fil., Paris, France.

Garfi, G., Barbero, M. \& Tessier, L. (2002) Architecture and growth patterns of Zelkova sicula (Ulmaceae) in south-east Sicily as a response to environmental conditions. Journal of Mediterranean Ecology, 3, 65-76.

Garfì, G., Carimi, F., Pasta, S., Rühl, J. \& Trigila, S. (2011) Additional insights on the ecology of the relic tree Zelkova sicula di Pasquale, Garfi et Quézel (Ulmaceae) after the finding of a new population. Flora, 206, 407-417.

GeoCAT (2012) Geospatial Conservation Assessment Tool. Royal Botanic Gardens, Kew, UK. Http://geocat.kew.org [accessed June 2011].
Hanski, I. (1998). Metapopulation dynamics. Nature, 396, 41-49. Holmgren, P.K. \& Holmgren, N.H. (1998) Index Herbariorum: a global directory of public herbaria and associated staff. New York Botanical Garden's Virtual Herbarium (continuously updated). Http://sciweb.nybg.org.

Hoshino, Y. (1990) Fruiting shoot as a wind-dispersed diaspore assisting the fruit dispersal of Zelkova serrata (Thunb.) Makino. Japanese Journal of Ecology, 40, 35-41.

IUCN (2010) Red List Categories and Criteria v. 8.1. IUCN, Gland, Switzerland. Http://www.iucnredlist.org [accessed June 2011].

JAHn, R. \& SCHÖNFELdER, P. (1995) Exkursionsflora für Kreta. Ulmer, Stuttgart, Germany.

Kozlowski, G., Gibbs, D., Huan, F., Frey, D. \& Gratzfeld, J. (2012a) Conservation of threatened relict trees through living ex situ collections: lessons from the global survey of the genus Zelkova (Ulmaceae). Biodiversity and Conservation, 21, 671-685.

Kozlowski, G., Frey, D., Fazan, L., Egli, B. \& Pirintsos, S. (2012b) Zelkova abelicea. In IUCN Red List of Threatened Species v. 2012.2. Http://www.iucnredlist.org [accessed June 2013].

Kozlowski, G. \& Gratzfeld, J. (2013) Zelkova-an ancient tree. Global status and conservation action. Natural History Museum Fribourg, Switzerland.

Kvavadze, E.V. \& Connor, S.E. (2005) Zelkova carpinifolia (Pallas) $\mathrm{K}$. Koch in Holocene sediments of Georgia-an indicator of climatic optima. Review of Palaeobotany and Palynology, 133, 69-89.

Milne, R.I. (2006) Northern Hemisphere plant disjunctions: a window on Tertiary land bridges and climate change? Annals of Botany, 98, 465-472.

Milne, R.I. \& Аввотт, R.J. (2002) The origin and evolution of tertiary relict floras. Advances in Botanical Research, 38, 281-314.

Quézel, P. \& Médail, F. (2003) Ecologie et Biogeographie des Forêts du Bassin Méditerranéen. Elsevier, Paris, France.

Rackham, O. \& Moody, J. (1996) The Making of the Cretan Landscape. Manchester University Press, Manchester, UK, and New York, USA.

Rechinger Fil., K.H. (1943) Neue Beitrage zur Flora von Kreta. (Ergebnisse einer biologischen Forschungsreise nach Peloponnes und nach Kreta 1942, im Auftrage des Oberkommandos der Wehrmacht des Reichforschungsrates, Nummer 6). Denkschriften der Akademie der Wissenschaften in Wien, mathematischnaturwissenschaftliche Klasse. 105. Band.

SARLIS, G.P. (1987) Zelkova abelicea (Lam.) Boiss., an endemic species of Crete (Greece). Webbia, 41, 247-255.

SCHULLE, W. (1993) Mammals, vegetation and the initial human settlement of the Mediterranean islands: a palaeoecological approach. Journal of Biogeography, 20, 399-412.

SøndergaArd, P. \& Egli, B.R. (2006) Zelkova abelicea (Ulmaceae) in Crete: floristics, ecology, propagation and threats. Willdenowia, 36 , 317-322.

Thompson, J.D. (2005) Plant Evolution in the Mediterranean. Oxford University Press, New York, USA.

Turland, N.J., Chilton, L. \& Press, J.R. (1993) Flora of the Cretan Area. HMSO, London, UK.

Van der Wiel, A.M. \& Wijmstra, T.A. (1987) Palynology of the lower part $(78-120 \mathrm{~m})$ of the core Tenaghi Philippon II, Middle Pleistocene of Macedonia, Greece. Review of Palaeobotany and Palynology, 52, 73-88.

Wang, Y.-F., Ferguson, D.K., Zetter, R., Denk, T. \& Garfì, G. (2001) Leaf architecture and epidermal characters in Zelkova, Ulmaceae. Botanical Journal of the Linnean Society, 136, 255-265.

ZHENG-YI, W. \& RAven, P.H. (eds) (2003) Zelkova. Flora of China. Vol. 5. Ulmaceae-Basellaceae. Missouri Botanical Garden Press, St. Louis, USA. 


\section{Biographical sketches}

GREGOR KOZLOWSKI's primary research interests are the conservation biology and biogeography of relict and endemic organisms. David Frey studies endemic taxa. LaUrence Fazan is a geographer with research interests in the dendrochronology of relict trees in the Mediterranean. BERNHARD EGLI has specialist knowledge of doline soils and the vegetation of the mountains of Crete.
SÉBASTIEN BÉTRISEY is studying the biogeography and conservation of Tertiary relict trees of south-west Eurasia. JoACHIM GRATZFELD specializes in the interface between people and biodiversity conservation. GIUSEPPE GARFI is a forest ecologist working on the biology and conservation of the woody plants of the Mediterranean; he discovered Z. sicula. Stergios Pirintsos is interested in the ecology and management of terrestrial ecosystems and in the ecology of rare and endemic plant species. 